\title{
TAXONOMIC STUDIES ON DINARMUS THOMSON (HYMENOPTERA: CHALCIDOIDEA: PTEROMALIDAE) OF INDIA AND ADJACENT COUNTRIES
}

\author{
P.M. Sureshan ${ }^{1}$ and T.C. Narendran ${ }^{2}$ \\ ${ }^{I}$ Zoological Survey of India, Western Ghats Field Research Station, Kamala Building, Annie Hall Road, Kozhikode, Kerala 673002, India. \\ Email: sureshpm2001@yahoo.co.in \\ ${ }^{2}$ Systematic Entomology Laboratory, Department of Zoology, University of Calicut, Kozhikode, Kerala 673635, India.
}

\begin{abstract}
Six species of Pteromalidae under the genus Dinarmus Thomson from India and adjacent countries are dealt with. Dinarmus maculatus (Masi) is redescribed based on the study of the lectotype deposited in MCSN. Diagnosis, biological data and distribution for all species are provided. A key to separate the Dinarmus species from India and adjacent countries is also provided.
\end{abstract}

Keywords

Dinarmus, Hymenoptera, Chalcidoidea, Pteromalidae

\begin{abstract}
Abbreviations
BMNH - Natural History Museum, London

BPBM - Bernice P. Bishop Museum, Honolulu, Hawaii

F1 - First funicular segment

MV - Marginal vein MCSN - Museo Civico di Storia Naturale, Giacomo Doria, Italy OOL - Ocell ocular distance PMV - Postmarginal vein POL - Post ocellar distance SMV - Submarginal vein STV-Stigmal vein T5 - Fifth tarsal segment UZIL - Universitetets Zoologiska Institutionen, Lund, Sweden USNM - United States National Museum, Washington DC. $\quad$ ZSIC - Zoological Survey of India, Kozhikode
\end{abstract}

\section{Introduction}

The genus Dinarmus Thomson (Pteromalidae: Pteromalinae) is distributed in all temperate, subtropical and tropical regions of the world (Boucek, 1988). All species of Dinarmus are known to attack bruchid beetles (Coleoptera: Bruchidae), which are serious pests of seeds of important pulse crops.

Rasplus (1989) in his revision of the Afrotropical species of Dinarmus treated the species under three species groups viz. D. acutus, D. altifrons and D. vagabundus. From India and adjacent countries six species of Dinarmus are currently known (Boucek et al., 1979; Farooqi \& Rao, 1986; Rasplus, 1989).

In this paper diagnosis and biological data of all the six species of Dinarmus known from India and adjacent countries are provided. D. maculatus (Masi) is redescribed based on the study of the lectotype deposited in MCSN. A key to separate the species dealt with is also provided.

The specimens of the present study are deposited in the collections of Zoological Survey of India, Western Ghats Field Research Station, Kozhikode.

The morphological terminology used in this paper follows that of Boucek (1988). 


\section{Genus Dinarmus Thomson}

Dinarmus Thomson 1878: 50, 56 (as subgenus of Dimachus Thomson).

Type species: Dinarmus acutus Thomson, designated by Ashmead, 1904.

Bruchobius Ashmead 1904: 314-315.

Type species: Bruchobius laticeps Ashmead, by original designation.

Metastenoides Girault 1915: 190.

Type species: Metastenoides simus Girault, by original designation. Syn. by Boucek, 1988: 413.

Oedaule Waterston 1922: 31.

Type species: Oedaule stringifrons Waterston by monotypy. Syn. by Boucek, 1988: 413.

Sphaerakis Masi 1924: 214.

Type species: Sphaerakis mayri Masi, by monotypy.

The genus can be easily distinguished by the following combination of characters:
Head large, not prominent behind eyes; anterior margin of clypeus shallowly emarginate or bidentate; female antenna with three and male with two anelli, third anellus sometimes quadrate; mesosoma stout, convex; pronotum as broad as mesoscutum, collar bluntly ridged or rounded, not sharply carinate, neck hardly visible from above; prepectus small, subquadrate; propodeum constricted into a subglobose nucha; forewing with stigma more or less capitate, sometimes costal cell enlarged; hind tibia with two spurs; gaster short.

\section{Dinarmus maculatus (Masi)}

(Figs. 1-4)

Sphaerakis maculatus Masi 1924: 157, Burma. Lectotype female (MCSN) examined.

\section{Material examined}

Lectotype: One female, vii.1886, det. J.Y. Rasplus 1984 (MCSN); 24 females, 22.xii.1985, Parambikulam, Kerala, India; six females, 16.v.1985, Silent Valley, Kerala, Coll. T.C. Narendran and party; two females, 25.v.1987, Kozhikode (Paroppady), Kerala, one male, i.1986, Kerala, Malampuzha, one male, 26.ii.1988, Neeleswaram, Kasaragod, Kerala, Coll. P.M. Sureshan; two females, Calicut University campus, Kerala, iii.1987, Coll. T.C. Narendran and

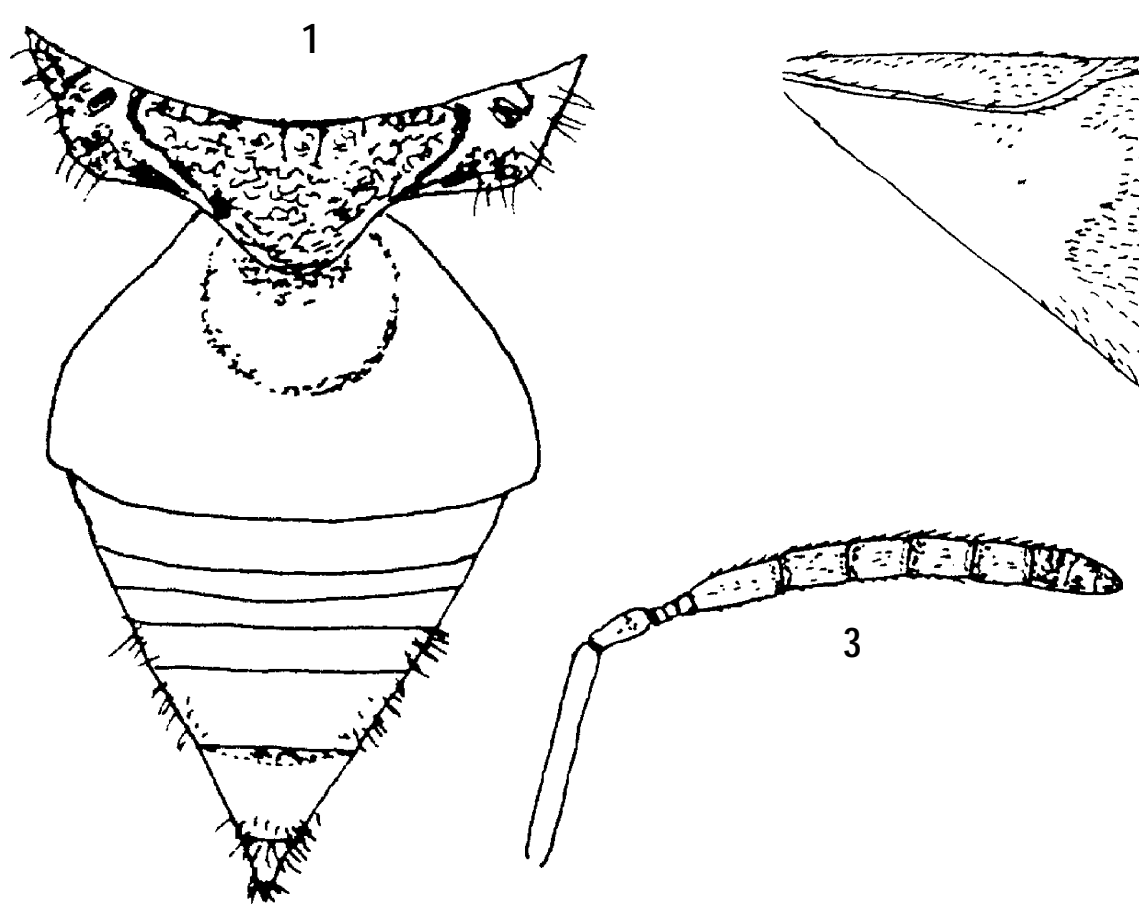

2

Figures 1-4. Dinarmus maculatus (Masi) (Female) 1 - Dorsal view of propodeum and gaster; 2 - Forewing; 3 - Antenna; 4 - Anterior margin of clypeus 
party in ZSIC.

\section{Distribution}

Burma; India: Calicut University campus, Paroppady, Kozhikode, Neeleswaram, Kasaragod, Malampuzha, Parambikulam, Silent Valley in Kerala; West Bengal.

\section{Biology}

Not known.

The species is redescribed here based on the study of the lectotype.

\section{Diagnostic features}

Female: Length $2.5 \mathrm{~mm}$. Body metallic blue with bronzy patches mainly on vertex and dorsal part of mesosoma except propodeum; gaster brown dorsally. Antennae yellowish brown except anelli and clava brown, similar brown bands on junctions of funicular segments. Coxae concolrous with mesosoma, femora and tibiae medially brown; base and apical $2 / 3$ portion of tibiae and all tarsi yellow. Tegule brown; wings slightly smoky, veins and pubescence pale brown.
Head: Reticulate punctate; clypeus striate, striae reaching lower margin of eyes. In dorsal view head width $2.4 \mathrm{x}$ length and in front view width $1.3 x$ height; temple length $0.5 x$ eye length; POL:OOL= 9:8; anterior margin of clypeus (Fig. 4) almost straight; eyes separated by $1.5 \mathrm{x}$ their height; malar space length $0.6 x$ eye height; scrobe deep, reaching median ocellus. Antennae (Fig. 3) inserted distinctly above lower margin of eyes, scape length $0.9 \mathrm{x}$ eye height, reaching middle of median ocellus, pedicel plus flagellum length $0.8 \mathrm{x}$ head width; third anellus as long as first and second combined; clava little shorter than two preceeding segments combined.

Mesosoma: Length $1.2 \mathrm{x}$ width, reticulate punctate; pronotum almost as wide as mesoscutum. Mesoscutum width $2 x$ length. Scutellum medially little shorter than mesoscutum (20:21.5). Propodeum (Fig. 1) medially $0.5 \mathrm{x}$ as long as scutellum, nucha moderate; plicae sharp; basal part of propodeum with short vertical rugae. Forewing (Fig. 2) length $2 x$ width; stigma moderately capitate. Relative lengths: SMV 31, MV 14, PMV 14, STV 9.5.

Gaster: (Fig. 1) Short and cordiform, dorsally collapsing, length 1.6x width; hypopygium reaching hind margin of $\mathrm{T} 5$.
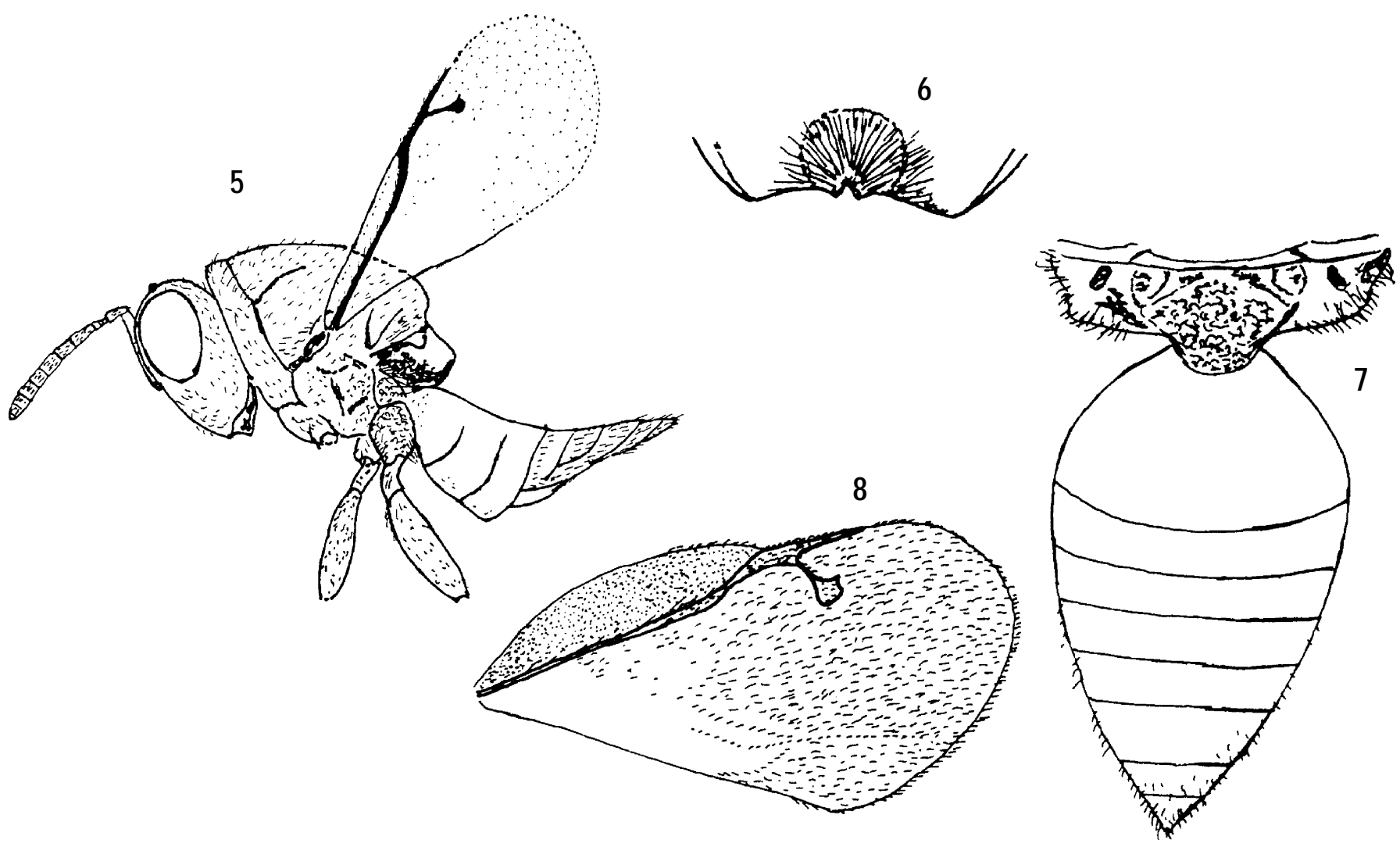

Figures 5-8. Dinarmus altifrons (Walker) (Female)

5 - Body in profile; 6 - Anterior margin of clypeus; 7 - Dorsal view of propodeum and gaster; 8 - Antenna of male 
Male: Length $2.1 \mathrm{~mm}$. Resembles female but differs in having antenna with two anelli and six funicular segments; gaster compressed with a broad yellowish spot at the base extending to middle; forewing more smoky with few setae on distal part of basal cell.

\section{Dinarmus altifrons (Walker)}

(Figs. 5-8)

Pteromalus altifrons Walker, 1862: 388.

Dinarmus stringifrons (Waterston), 1922: 32.

Male, India (Dehradun) (BMNH) syn.by Rasplus, 1989: 149.

\section{Material examined}

Five females, ii. 1991, Coimbatore, Tamil Nadu, India, ex. Seeds of Albizia lebbeck, Coll. Madhavan Pillai \& party (ZSIC).

\section{Distribution}

Africa; Israel; Pakistan; India: Dehradun in Uttaranchal; Punjab; Delhi; Coimbatore in Tamil Nadu.

\section{Biology}

Specimens for the present study were collected as emerged from mature seeds of Albizia lebbeck. The other recorded biological informations are ex. pods of Pueraria tuberosa; ex. Bruchids on Sesbania acutifolia; ex. Bruchids (Boucek et al., 1979).

\section{Diagnostic features}

Female: Length $2.2-4.2 \mathrm{~mm}$. Body metallic green with bronzy reflection; gaster brown with bluish reflection; antennae brown; head reticulate, punctate with dense pubescence; clypeus (Fig. 6) sharply bidentate; POL 2x OOL; antennae (Fig. 5) inserted above lower margin of eyes, scape reaching median ocellus; mesosoma convex, reticulate punctate; notaular grooves reaching just above hind margin of mesoscutum; propodeum coarsely reticulate; basal foveae deep; plicae weakly indicated, almost complete; forewing with discal pubescence almost indistinct.

Gaster: (Fig. 7) elongate, ovate, dorsally collapsing.

Male: Length 2-3.8mm. Resembles female but differs in having antenna with two anelli and six funicular segments; forewing (Fig. 8) with costal cell enlarged with numerous minute bristles and gaster short and compressed.

\section{Dinarmus basalis (Rondani)}

(Figs. 9, 10)

Entedon basalis Rondani, 1877: 174.

Male, Italy (Lectotype, Florence Museum).

For various synonyms see Rasplus, 1989: 135-162.

\section{Material examined}

Two females, 1997, Calicut University campus, Kerala, India, Coll. T.C. Narendran and party (ZSIC).

\section{Distribution}

America; Pakistan; India: Calicut University campus in Kerala; Delhi; Andhra Pradesh; Bihar; Haryana; Rajastan; Karnataka.

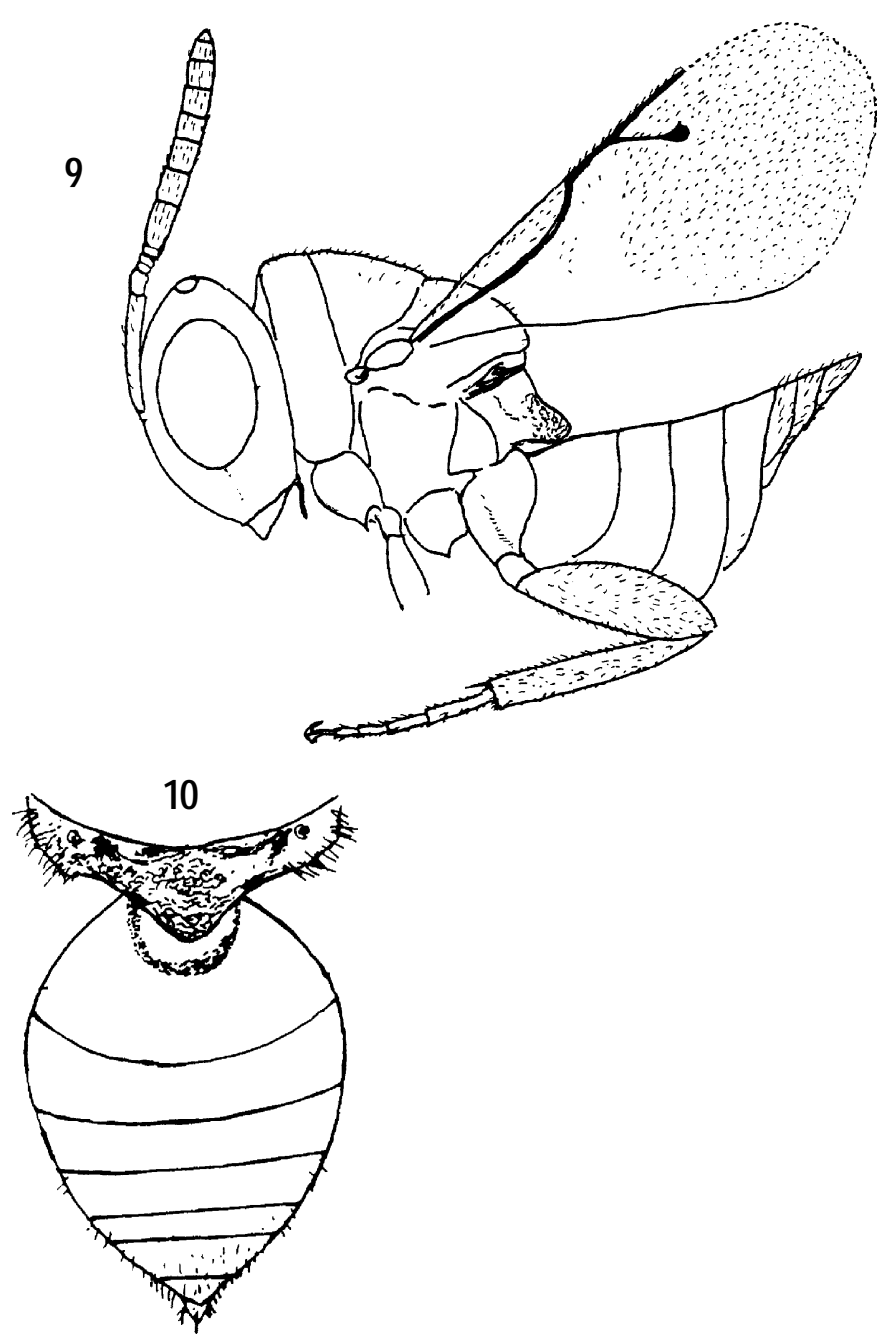

Figures 9-10. Dinarmus basalis (Rondani) (Female) 9 - Body in profile; 10 - Dorsal view of propodeum and gaster 


\section{Biology}

Ex. Trogoderma granarium (Coleoptera: Dermestidae), Callosobruchus chinensis, Callosobruchus maculatus, Callosobruchus analis, indet. Bruchids (Coleoptera: Bruchidae) (Boucek et al., 1979; Farooqi \& Rao, 1986).

\section{Diagnostic features}

Female: Length $2.2-2.7 \mathrm{~mm}$. Dark green with brassy reflection; antennae with scape, pedicel and anelli testaceous, remainder brown; coxae concolrous with mesosoma, femora brown; remainder of legs testaceous.

Head: $1.2 \mathrm{x}$ as broad as mesosoma; moderately reticulate; POL 1.3x OOL; anterior margin of clypeus weakly emarginate; antennae (Fig.9) inserted little above lower margin of eyes, scape hardly reaching median ocellus; pedicel shorter than $\mathrm{Fl}(0.6 \mathrm{x})$; third anellus longest.

Mesosoma: Reticulate punctate; scutellum medially little shorter than mesoscutum (17:18); propodeum with nucha highly constricted; forewing with few hairs on basal hairline; pubescence sparse; marginal fringe absent; PMV longer than MV.

Gaster: (Fig. 10) ovate, length 1.4x width in dorsal view; dorsally flat, slightly collapsing.

\section{Dinarmus vagabundus (Timberlake)}

(Fig. 11)

Bruchobius vagabundus Timberlake, 1926: 305. Female. USA (Hawaii), Honolulu (BPBM).

For various synonyms see Rasplus 1989: 135-162.

\section{Material examined}

Three females, 24.ii.1995, Calicut University campus, Kerala, India, Coll. S. Sheela from stored pulses infested with Bruchids.

\section{Distribution}

Pakistan; Sri Lanka; India: Calicut University campus in Kerala; Karnataka; Punjab; Tamil Nadu.

\section{Biology}

Common parasites of various Bruchid beetles.

\section{Diagnosis}

Female: Length 1.8-2.6mm. Head and mesosoma black without metallic reflection; gaster brownish black; head finely and closely reticulate with short white pubescence, $1.1 \mathrm{x}$ as broad as mesosoma and width $2 \mathrm{x}$ length in dorsal view; anterior margin of clypeus weakly emarginate; POL:OOL=6:5; scape reaching median ocellus; little shorter than eye; pedicel as long as F1,

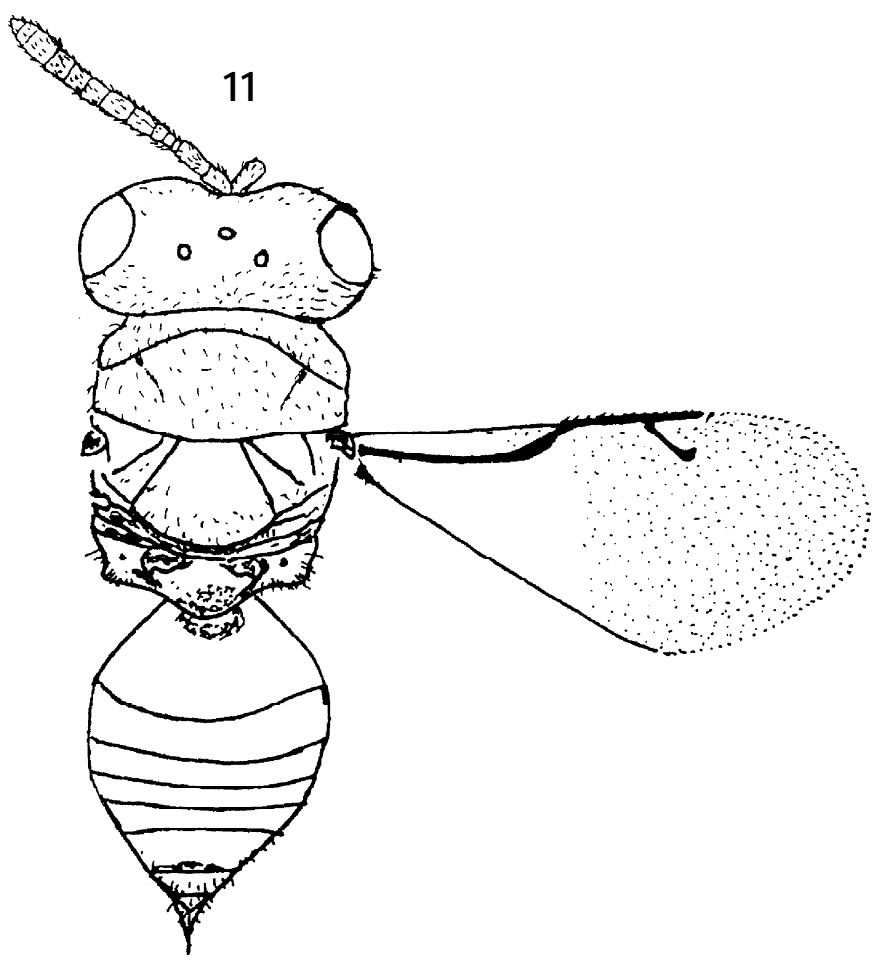

Figure 11. Dinarmus vagabundus(Timberlake) (Female) 11 - Body in dorsal view

third anellus quadrate, clava little longer than two proceeding segments combined.

Mesosoma: Convex, reticulate punctate; mesoscutum width 2.3x length; scutellum medially as long as mesoscutum; propodeum with nucha short; forewing with discal pubescence very short and indistinct; marginal fringe absent, PMV as long as STV.

Gaster: Broadly ovate, shorter than head plus mesosoma combined $(0.8 \mathrm{x})$, dorsally collapsing. 


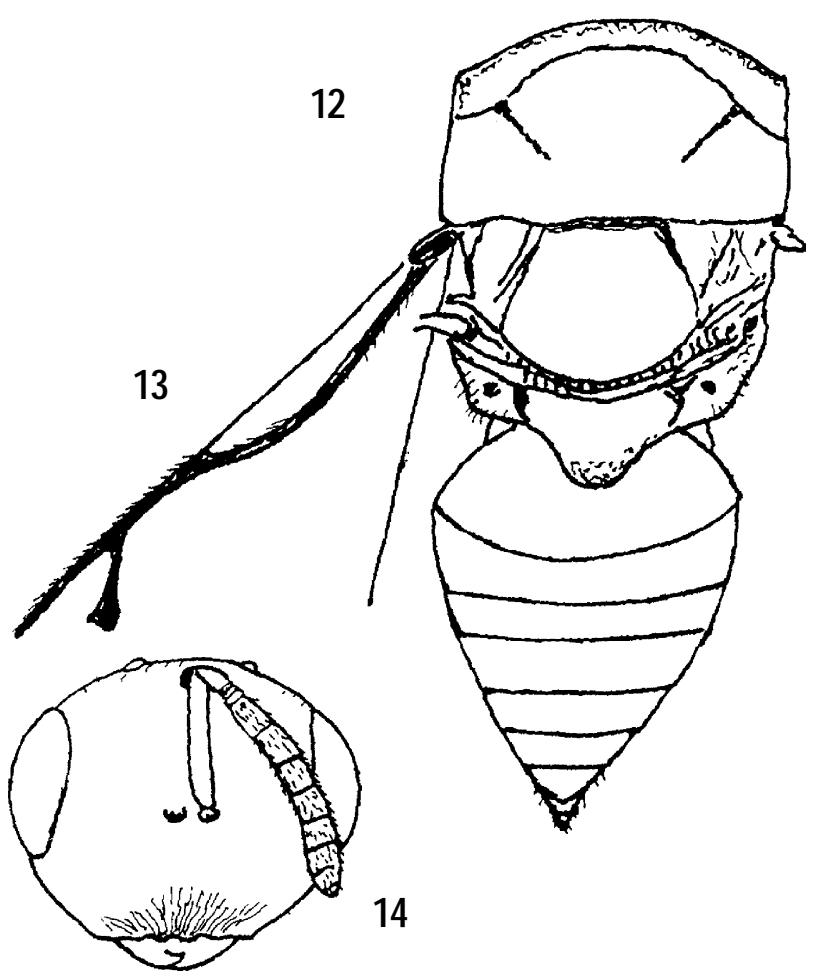

Figures 12-14. Dinarmus acutus (Thomson) (Female) 12 - Dorsal view of mesosoma and gaster; 13 - Forewing; 14 - Head in front view

\section{Dinarmus acutus (Thomson)}

(Figs. 12-14)

Dimachus (Dinarmus acutus) Thomson, 1878: 56. Female, Boheman(UZIL).

For various synonyms see Rasplus 1989: 135-162.

\section{Material examined}

Two females, 14.i.1986, Malampuzha, Kerala, India; 15 females, 20 males, 1985-1988, Calicut University campus, Kerala, India, Coll. T.C. Narendran and party; two females, one male, 25.ii.1988 Kasaragod (Periya), Kerala, India; three females, Kozhikode, Kerala, 24.vi.1987, Coll. P.M. Sureshan (ZSIC).

\section{Distribution}

Europe; India: Malampuzha, Calicut University campus, Kozhikode, Periya, Kasaragod in Kerala.

\section{Biology}

Common parasites of Bruchid beetles.

\section{Diagnostic features}

Female: Length: 1.5-2.4mm. Body dark metallic blue; gaster darker; antennae with scape testaceous, remainder brown; coxae concolrous with mesosoma, femora and tibiae brown.

Head: (Fig. 14) moderately reticulate punctate with small white pubescence; anterior margin of clypeus emarginate, weakly bidentate; POL 1.6x OOL; scape almost reaching upper margin of median ocellus, length $0.9 \mathrm{x}$ eye height; pedicel as long as $\mathrm{Fl}$; anelli transverse; clava almost as long as two preceeding segments combined.

Mesosoma: (Fig. 12) reticulate punctate; pronotum as broad as mesoscutum; mesoscutum width $1.8 x$ length; scutellum medially 0.8x mesoscutum; propodeum with nucha distinct; forewing (Fig. 13) with PMV as long as MV.

Gaster: Ovate, acuminate, not collapsing. In dorsal view length $1.4 \mathrm{x}$ width and $0.7 \mathrm{x}$ as long as head plus mesosoma combined.

Male: Length 1.3-1.5mm, resembles female but differs in having antennae with two anelli and six funicular segments; gaster shorter and oval with a broad yellow spot at base extending more than half length dorsally.

\section{Dinarmus colemani (Crawford)}

(Figs. 15, 16)

Bruchobius colemani Crawford, 1913: 250. Female, India (Bangalore) (USNM).

\section{Material examined}

One female, 1982, Changaramkulam, Thrissur Distrtict, Kerala, India, Coll. T.C. Narendran (ZSIC).

\section{Distribution}

Bangladesh; India: Changaramkulam, Thrissur in Kerala; Bihar; Delhi; Karnataka; Tamil Nadu.

\section{Biology}

Ex. Callosobruchus chinensis on grass and wild chillies (Boucek et al., 1979).

\section{Diagnostic features}

Female: Length $2.4 \mathrm{~mm}$. Body bluish black with metallic reflection laterally; gaster brownish black with metallic blue reflection basally; antennae testaceous; anelli brown and narrow brown rings at the junctions of funicular segments.

Head: (Fig. 15) narrow in profile, reticulation and pubescence as in D. basalis; POL $1.5 \mathrm{x}$ OOL; temple length $0.4 \mathrm{x}$ eye length; anterior margin of clypeus slightly projecting medially. Antennae inserted distinctly above lower margin of eyes, scape reacing up to 3/4 length of median ocellus, little shorter than eye; pedicel 


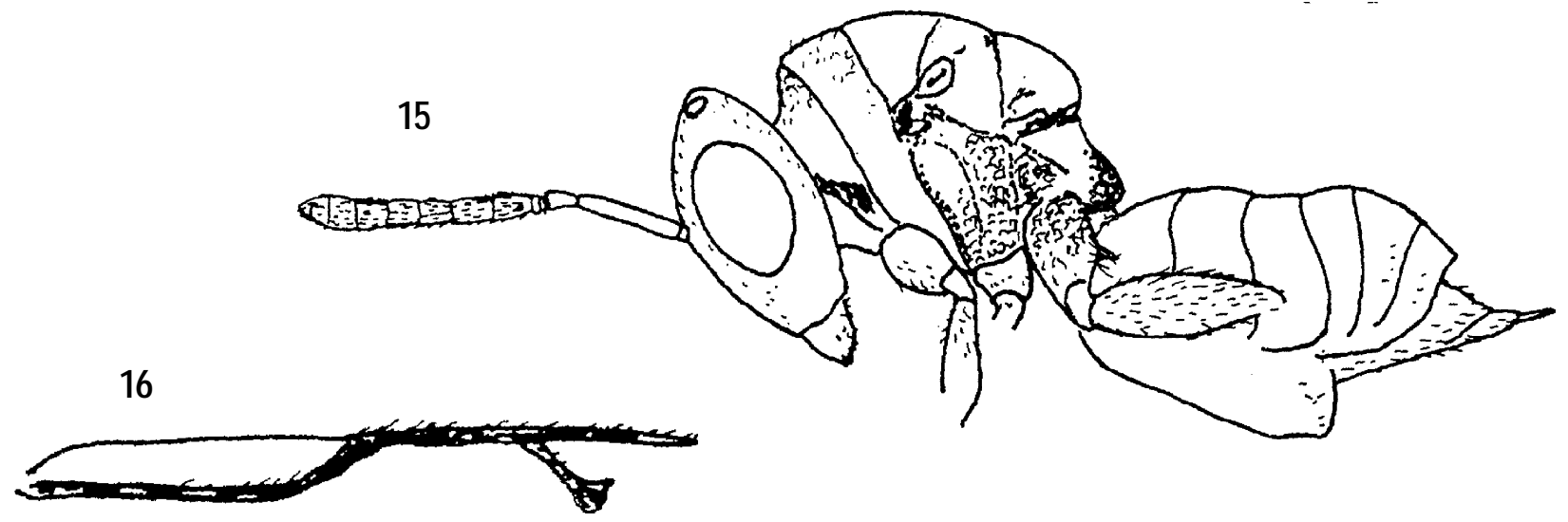

Figures 15-16. Dinarmus colemani (Crawford) (Female) 15 - Body in profile; 16 - Forewing venation

plus flagellum length almost equal to head width; pedicel little shorter than Fl; anelli, transverse, third longest; clava as long as two preceeding segments combined.

Mesosoma: (Fig. 15) reticulate punctate; mesoscutum medially little longer than scutellum $(16.5: 15.5)$; propodeum with nucha distinctly projecting. Forewing (Fig. 16) with stigma moderately capitate, PMV little shorter than MV.

Gaster: Ovate, dorsally slightly collapsing, sub-equal to head and mesosoma combined.

\section{Acknowledgements}

The first author is grateful to the Director, Zoological Survey of India, Kolkota and the Officer-in-charge, Zoological Survey of India, Western Ghats Field Research Station, Kozhikode for providing facilities and encouragement. We are thankful to Dr. Valter Reineri, MCSN, Genova, Italy for providing the type material on loan and Dr. Steven Heydon, University of California, Davis, USA for providing relevant literature on Pteromalidae.

\section{References}

Ashmead, W.H. (1904). Classification of the chalcid flies or the superfamily Chalcidoidea with descriptions of new species in the Carnegie Museum collected in South America by Herbert, H. Srnith. Memoirs of the Carnegie Museum 1(4): i-xi. 225-551.

Boucek, Z. (1988). Australasian Chalcidoidea (Hymenoptera ) CAB International, Wallingford, U.K., 832 pp.

Boucek, Z., B.R. Subba Rao and S.I. Farooqi (1979). A preliminary review of Pteromalidae (Hymenoptera) of India and adjacent countries Oriental Insects 12: 433-467.

Crawford, J.C. (1 913). Descriptions of new Hymenoptera. No. 6.
Proceedings of the United States National Museum 45: 241-260. Farooqi, S.I. and B.R. Subba Rao (1986). Family Pteromalidae pp. 254-263. In: Subba Rao, B.R. and M. Hayat (Editors). The Chalcidoidea (Insecta: Hymenoptera) of India and the adjacent countries. Part 11. A Catalogue. Oriental Insects 20: 1-430.

Girault, A.A. (1915). Australian Hymenoptera Chalcidoidea-VIII. The family Miscogasteridae with descriptions of new genera and species. Memoirs of the Queensland Museum 4: 185-202.

Masi, L. (1924). Note sui generi Bruchobius, Oedaule, Sphaerakis con descrizione di nuove specie (Hymen. Chalcididae). Annali di Museo Civico di Storia Naturale di Giacomo Doria 5(1): 149-160.

Rasplus, J.Y. (1989). Revision des especes Afrotropicales Du genre Dinarmus Thomson (Hymenoptera: Pteromalidae). Annsales de la Societe Entomologicue de France (N.S.) 25(2): 135-162.

Rondani, C. (1877). Vesparia parasitica non vel minus cognita. Bollettino della Societa Entomologica Italiana 9: 166-213

Thomson, C.G. (1878). Hymenoptera Scandinaviae. 5. Pteromalus (Svederus) continuation, 307 pp., 1 pl. Lundae.

Timberlake, P.H. (1926). New species of Hawaiian Chalcid flies (Hymenoptera). Proceedings of the Hawaiian Entomological Society 6: 305-320.

Walker, F. (1862). Notes on Chalcidites, and characters of undescribed species. Transactions of the Royal Entomological Society of London (3): 1, 345-347.

Waterston, J.C. (1922). On Chalcidoidea (mainly bred at Dehra Dun, U.P. from pest of Sal, Toon, Chir and Sundri). Indian Forest Records 9: $1-44$. 


\section{Key to the Dinarmus species of India and adjacent countries.}

1. Anterior margin of clypeus (Fig. 6) with distinct median indent; forewing (Fig. 5) with discal pubescence very sparse, almost indistinct; stigmi strongly capitate; costal cell enlarged in male (Fig. 8); POL 2x OOL; propodeal nucha short (Fig. 7) D. altifrons

1A. Anterior margin of clypeus almost straight, shallowly emarginate or very weaklv bidentate (Figs. 4, 14), not as above; forewing with discal pubescence not reduced as above; stigma normal or moderately capitate, costal cell not enlarged; nucha moderately or distinctly projecting; POL less than 2x OOL .... 2

2. Forewing (Fig. 11) with PMV distinctly shorter than MV (0.6x) and only as long as STV; discal pubesence very short and less distinct. POL only slightly longer than OOL (6:5) D. vagabundus

2A. PMV as long as, little longer or shorter than MV, but distinctly, longer than STV; discal pubescence distinct; POL, distinctly longer than OOL

3. Anelli transverse, third anellus not longer than second (Figs. 14, 15) ..............................................

3A. Third anellus distinctly longer than second and as long as first and second combined (Figs. 3, 9) ...... 5

4. Anterior margin of clypeus weakly sinuate (Fig. 14); antennae with pedicel as long as Fl; forewing (Fig. 13) with PMV as long as MV; gaster short, not collapsing, $0.7 \mathrm{x}$ as long as head plus mesosoma combined

D. acutus

4A. Anterior margin of clvpeus almost straight -.pedicel little shorter than F1 (Fig. 15); PMV 0.8x as long as MV (Fig. 16); gaster long, dorsally slightly collapsing, sub-equal to head plus mesosoma combined ....

D. colemani

5. Anterior margin of clypeus almost straight (Fig. 4), not projecting. PMV as long as or slightly longer than MV (Fig. 2); antennae slender (Fig. 3) with scape reaching middle of median ocellus, yellowishbrown except anelli and clava brown; similar brown bands at junctions of funicular segments; POL, subequal to OOL, gaster (Fig. 1) highly cordiform

D. maculatus

5A. Anterior margin of clypeus shallowly emarginate, slightly projecting; PMV 1.3x OOL; antennae (Fig. 9) not slender; scape hardly reaching median ocellus, uniformly yellowish-brown or brown; funicular segments without brown rings. POL 0.3x OOL; gaster not cordiform (Fig. 10) .....

D. basalis 